\title{
Konzervatizmus és információs társadalom
}

A szerző álláspontja szerint a modern információs társadalom nem hozott magával teljesen új problémákat, mivel az ebben a fogalomkörben felvetett jellegzetes kérdések gyakorlatilag egyidősek a nyugati civilizációval. Ennélfogva a konzervatív gondolkodás számára is jól ismert, klasszikus kérdésekről van szó, tehát semmiképpen sem igaz, hogy a konzervatív felfogás számára az információs társadalom elvileg is új kihívást jelent. Mindezt a tanulmány a konzervatívok szemében általában kiemelten fontos négy kérdéskör, a hagyomány, a rend, a funkció és a tudás (a tudomány) jelenségcsoportjainak elemzésével támasztja alá. Az igazi konzervatív gondolkodás semmiképpen sem ellenséges vagy gyanakvó az információs technológiák fejlődésével és terjedésével szemben. Mivel lényeges társadalmi változások nem rajzolódnak ki a horizonton, a szerző következtetése szerint fennmaradnak a klasszikus kérdések és érvényesek a klasszikus válaszok is.

Kulcsszavak: konzervatizmus, információs társadalom, hagyomány, rend, funkció, tudás

\section{Szerzői információ:}

\section{Balázs Zoltán}

Közgazdász és politológus, a Pázmány Péter Katolikus Egyetem Szociológiai Intézetének docense, a Századvég címú folyóirat fốszerkesztôje.

E-mail:balazszoltan1@t-online.hu

Így hivatkozzon erre a cikkre:

Balázs Zoltán. „Konzervatizmus és információs társadalom”.

Információs Társadalom VI, 4. szám (2006): 47-60.

https://dx.doi.org/10.22503/inftars.VI.2006.4.6

A folyóiratban közölt müvek

a Creative Commons Nevezd meg! - Ne add el! - Így add tovább! 4.0

Nemzetközi Licenc feltételeinek megfelelöen használhatók. 
Balázs Zoltán

\section{Konzervatizmus és információs társadalom}

Ha valaki akár csak futólag is áttekinti az információs társadalommal kapcsolatos internetes forrásokat, a következő kifejezések minden bizonnyal megragadnak az emlékezetében: „,információ kora”, „információrobbanás”, „globális társadalom”, „,információhoz való jog”, „hálózat”, „technológiai-tudományos forradalom”, „lemaradás”, „internet”, „kommunikáció” stb. Az persze, hogy mi ragad meg az olvasó fejében, nyilvánvalóan nemcsak szintaktikai kérdés, amit tartalomelemzéssel egzakt módon rekonstruálni lehet, hanem annak is függvénye, hogy az olvasónak milyen elózetes várakozásai vannak, azaz mire érzékeny. Az érzékenység pozitív és negatív is lehet. Vagy tartunk attól, amire számítunk, esetleg unjuk, utáljuk, lehangolónak találjuk; vagy pedig vonz, inspirál, lelkesít és valamiben megerốsít minket. Könnyen lehetséges, hogy ezzel a fogalomlistával kapcsolatban a legtöbben úgy vélekednének, hogy a haladás- és változáspárti világnézetet vallók számára a lista vonzó, lelkesítő és munkára ösztönző, míg a haladást és a változást fenntartásokkal fogadók számára inkább taszító, félelemkeltô, gyanús. Innen pedig csak egy lépésre vagyunk attól, hogy az információs társadalom és a hozzá tapadó képzetek fogalomkörében is a progresszív-liberális és a reakciós-konzervatív felfogás ütközésének egyik terepét lássuk meg. A „liberális” elfogad, sốt, üdvözöl és kiterjeszteni törekszik minden olyan folyamatot, ami az információáramlás szabadságát, kapcsolatszervező képességét erôsíti, a „konzervatív” viszont gátolni, ellenőrizni, korlátozni kívánja ugyanezt. Ezek sarkított álláspontok, s nem kizárt, hogy egyetlen liberális vagy konzervatív szerző sem fogadná el fenntartások és lényegi kiegészítések nélkül az itt röviden meghatározott felfogást. Nem arra törekszem azonban, hogy „a” liberális és „a” konzervatív filozófiát rekonstruáljam, hanem arra, hogy egy közkeletúnek mondható és ekként kiindulópontnak elfogadható elméleti pozíciópárt határozzak meg.

A következő fejtegetések célja az, hogy ezt a felfogást megingassák. Kiindulópontom szerint az információs társadalomnak nevezett „tünetegyüttesnek” egyik fontosabb eleme sem újkeletû, hanem valamennyi a nyugati társadalom-és politikafejlődés szerves összetevóje. Ennélfogva a konzervatív felfogás számára a technológiai változások semmiképpen sem jelentenek új társadalmi kihívást, legföljebb némelyiket megerôsítik, hangsúlyozottabbá teszik. Ezt a tézist négy olyan történelmi folyamat és jelenségcsoport szükségképpen elnagyolt, de remélhetóleg meggyőzố elemzésével igyekszem alátámasztani, amelyeknek a legtöbb konzervatív általában nagy jelentôséget tulajdonít. Mindegyiknek megvannak a maga sajátos információs problémái és vonatkozásai, következésképpen ezekkel a konzervatív magyarázatnak is szembe kell néznie. 


\section{Az információs társadalom régisége}

Azzal, hogy egy társadalmat ,információsnak” nevezünk, voltaképpen tautológiát állítunk. Minden társadalom ,információs”, ideértve az állatvilágban ismert társulásokat is, sốt, voltaképpen az „élet” egyik titka az információátadás problémájának megbízható és hatékony megoldása. Minden új egyed valamilyen információtömeg többé-kevésbé stabil rekonstrukciója, illetve - az élet magasabbrendû szintjein - két információhalmaz kombinációja. Még magasabb szinten a gének determináló szerepe után az „információhalmazok” - az egyedek - aktív információátadási tevékenységével is számolunk. Ez a tevékenység maga is információvá válhat, azaz normákat, szabályokat és eljárásokat teremthet, amelyek ugyancsak elsajátíthatók és elsajátítandók. Ezek már nem egyéni, hanem társas, az egyénektól független, illetve generalizált tapasztalatok, tudásformák, amelyek az egyének számára ilyen vagy olyan okokból fontos ismereteket - információkat - közvetítenek. Ám ezzel még mindig csak a legprimitívebb, illetve legarchaikusabb emberi közösségeknél járunk. A következő fontos lépésnek az látszik, hogy az információ közvetítésének, strukturálásának, válogatásának stb. formái és eljárásai mint ilyenek válnak fontossá, a tudásszerzés célpontjaivá. Ezt nevezhetjük az emberi közösségek és társulások társadalmi öntudatra ébredésének is: 1. a hagyomány depozitummá, letéteménnyé válik; 2 . az eljárások és szokások renddé válnak; 3. az intézmények funkciót töltenek be; 4. a tudás gyarapítandó lesz és az ismeretlenre, a jövốre irányul. ${ }^{1}$ Ennek a folyamatnak van számos technikai-technológiai mozzanata (elsósorban a tudásformák és az információk rögzítési technikájára gondolok: írás, könyvnyomtatás, könyvtár, enciklopédiák, szótárak, kézikönyvek); ${ }^{2}$ továbbá nyilvánvaló biológiai feltételei (elegendôen hosszú életkor, megfeleló létszámú társadalom, a biológiai túlélés napi gondjainak fölszámolása). Mindent összevetve az az aligha meglepó állítás körvonalazódik, hogy tág értelemben véve minden társadalom szükségképpen „információs”, szúk értelemben véve viszont az az információs társadalom, ahol az információ, a tudás, az ismeret mint ilyen okoz különbözô problémákat, vet föl kérdéseket és idéz elő konfliktusokat.

Mindezzel persze nem a nyugati civilizáció „modern” korszakának társadalmait specifikáltuk. Az imént felsorolt jellegzetességek mindegyike évezredes múltra tekinthet benne vissza. A hagyomány magától értetôdố volta a görög filozófia óta kérdéses. A rend mint alkotmány, mint jogrendszer szintén a görög és római gondolkodás egyik jellegzetes témája. A funkció elemzése, a munkamegosztás-elmélet ugyanilyen régi gondolatkör. ${ }^{3}$ A tudás mint rendszerezett tudomány Arisztotelész óta többé-kevésbé ismert. Természetesen egyik-másik mozzanatra egy adott korban váratlan vagy legalábbis új-

${ }^{1}$ Komplex civilizációelméleti monográfiákban nyilvánvalóan folytatni kellene a sort, tézisem szempontjából azonban a teljességnek nincs jelentôsége. Elég, ha ezek a kulcsfontosságú szempontok megfelelố bizonyítćkot szolgáltatnak hozzá. Kiválasztásuknál a bevezetôben említett szempontot tartottam szem elốtt: a konzervatív politikai filozófiában ezek a fejlemények általában nagy figyelmet kapnak. S még egy tisztázó megjegyzés: nem állítom, hogy ezek a fejlemények mindegyike kizárólag a nyugati civilizációban jelentkezik; azt azonban igen, hogy együttvéve csak erre a civilizációra jellemzốck.

${ }^{2}$ Vö. Nyíri Kristóf: „Hagyomány és szóbeliség”. In A hagyomány filozófiája. Budapest, 1994, T-Twins, Lukács Archívum, 13-47. o.

${ }^{3}$ Vö. Platón: Az állam, 368b-375e (in Összes múvei. Budapest, 1984, Európa). 
szerû módon vetült fény. A reformáció kiélezte az ellentétet „könyv” és „hagyomány” között. A „rend” többször összeomlott vagy összeomlással fenyegetett, amire válaszul forradalmak vagy forradalmi elméletek születtek. A funkciók kiteljesedtek vagy differenciálódtak, noha - legalábbis az észlelés számára - nem egyenletesen: sokak szemében a középkori társadalom differenciáltabbnak túnt vagy túnik még ma is a kapitalista társadalomnál (ez kiváltképpen igaz a baloldali - marxista, frankfurtiánus - kritikusokra). Mások (például Niklas Luhmann) fordítva gondolják. A tudomány mint információgyarapítás elôször a középkori iskolákban, egyetemeken, majd a természettudósok magángyưjteményeiben, laboratóriumaiban, házikönyvtáraiban, késốbb ismét az egyetemeken és kutatóintézetekben összpontosult. Ebból tehát az a következtetés adódik, hogy még a „modern” értelemben vett „információs” társadalom is egyidôs az európai civilizációval. Mivel pedig az európai, illetve nyugati civilizáció egyik meghatározó politikaelméleti tradíciója a konzervativizmus, azt kell mondanunk, hogy a konzervatív felfogás lényegi és állandó reflexió mindazokra a problémákra, amelyeket az ismeretek felhalmozásának, tárolásának, közvetítésének és továbbításának a sajátosságai és módszerei vetnek föl. A továbbiakban a fölsorolt és röviden jellemzett négy jelenségcsoporton megyek végig, részletesebben elemezve óket.

\section{A hagyomány}

Azt állítottam, hogy a nyugati gondolkodásban a hagyomány letéteménnyé vált. Másként fogalmazva: a hagyományra mint hagyományra tekintünk, azaz olyasvalamire, ami ugyan tekintéllyel rendelkezik vagy rendelkezhet, de ezt a tekintélyt nem önmagából meríti. Ha önmagából merítené, nem is tekinthetnénk rá hagyományként. ${ }^{4}$ Hogy világosabb legyen, miról van szó, hadd utaljak a teológiában - különösen a katolikus teológiában - jól ismert „szenthagyomány” fogalmára. ${ }^{5} \mathrm{Ez}$ a hagyomány az Írás kommentárjait, az egyház által elismert magyarázó-kommentáló egyházatyák és teológusok múveit, az egyház részéról általában jóváhagyott (de nem föltétlenül dogma rangjára emelt) magyarázatokat és értelmezéseket foglalja magában. A tanítás szerint ez a hagyomány ismeretek forrása, egyenrangú a Szentírással. Közismert, hogy ezt a tételt a protestantizmus élesen bírálta. Bírálatának döntô oka az volt, hogy ha a hagyományt ismeretek forrásának tekintjük, akkor végsô soron az Írás fölé állítjuk, vagyis az utóbbit lefokozzuk, s ezzel meghamisítjuk, s könnyen lehetséges, hogy emberi, búnös célok érdekében. De vajon valóban ezt jelenti a hagyomány mint ismeretforrás? Nézetem szerint nem. Az ismeretforrás ebben az összefüggésben nem önálló, s éppen ezért potenciálisan az Írás fölé kerekedó autoritást jelent, hanem az elkerülhetetlenül szaporodó értelmezési kényszerhelyzeteknek való megfelelés autoritását, magyarán alkalmazott, gyakorlati autoritást. A hagyomány igazságát mindig alá kell támasztani az Írással: ezért nem meríti önmagából saját tekintélyét. Ső́t, a magyarázat, az értelmezés sem nélkülözheti a speciális külsốmegerôsítést, azaz a Szentlélek közvetlen irányítását. A hagyomány

${ }^{4}$ Lásd ehhez Tamás Gáspár Miklós klasszikus tanulmányát: „Vázlat a hagyományról”. In Idola Tribus, 246-274. o. Párizs, Magyar Füzetek Könyvei, 12.

${ }^{5}$ Terrence W. Tilley: Inventing Catholic Tradition. New York, 2000, Maryknoll. 
tehát csak úgy és abban az értelemben ismeretforrás, ahogyan és amilyen értelemben azt maga az Î́rás megengedi.

Ebból következik, hogy maga a hagyomány is értelmezendố, magyarázandó ismeret. De olyan ismeret, amely a rá való reflexió révén önmagától gyarapszik. Ez a gyarapodás, bôvülés adhatja azt a képzetet, hogy a hagyomány „önjáró”, vagyis minden értelmezố számára súlyos külső tekintély. S ez így is van: a hagyományt tilos megkerülni. De nem lehet fölolvasni sem. Nem lehet bemutatni. Igazából még csak rámutatni sem lehet. A hagyomány ugyanis mindenekelốtt állandóan keletkezố, formálódó ismeret. Olyan ismeret, amely egyszerre egyének múve, ugyanakkor közös termék, a hagyományban részt vevốk közös produktuma. A hagyomány nyújtotta ismeretre reflektáló személy valamilyen aktuális magyarázandó problémára keresi a megoldást. Ez a probléma viszont, bár teljességgel magánjellegû́nek is túnhet, részben mégis rajta kívül álló, azaz más emberek tevékenysége, viselkedése okozta körülmények miatt állt elő. A kérdés is közös, a megoldás is az. Ha tanácsot kér valaki, akkor a sikeres tanácsadásnak az a feltétele, hogy a magyarázó és a hallgató ne értse félre egymást, azaz mindketten benne álljanak a hagyományban.

A hagyomány tehát nem beszél önmagáért, a hagyományt megszólaltatni lehet csupán, de ahhoz elóbb el kell fogadni. Vannak olyan hagyományok (köztük az idézett vallási, gondolkodási hagyományok is), amelyek elsôsorban igazságértékükre hivatkoznak: hitelesítójüu az igazság. Más hagyományok például esztétikai értékükre hivatkoznak. Vannak családi, nemzeti hagyományok, és vannak különféle lokális, intézményi hagyományok is, amelyek hitelességének, tekintélyének forrása nem az igazság, hanem például az identitást megtartó, illetve teremtô képesség. Még a mesterségbeli hagyományok, tudásformák és ismeretanyagok esetében is meg lehet ragadni ezt a külső tekintélyt: az elóállított dolog, termék hasznossága az, ami azt hitelesíti, elfogadásra méltóvá teszi.

Az a kijelentés, hogy a hagyomány letétemény, azt jelenti, hogy ismeri a különbséget a kifelé és a befelé irányuló beszédmód között. Csatlakozásra hív, de egyúttal el is zárja önmagát azzal, hogy olyan ismereteket tartalmaz, amelyeket csak a csatlakozás után lehet megszerezni. Ez így van még a legegyszerúbb esetben, az imént említett mesterségek esetében is: a kézikönyv, amely a dolgok előállítását próbálja elmagyarázni, kifelé szól. Ám ahhoz, hogy a dolgot tényleg elő tudja valaki állítani, az kell, hogy ismerje a befelé szóló „leírást” is, azaz mindazokat a gyakorlati fogásokat, amelyek csak ismétlés és gyakorlás, de nem könyvból való tanulás révén sajátíthatók el (s amelyek szoros értelemben véve nem is ,írhatók le" ). ${ }^{6}$

A hagyományban benne élók is tudják, hogy amit csinálnak, az nem magától értetôdő, még akkor sem, ha számukra személyesen elképzelhetetlen volna nem magától értetôdoón helyesnek, igaznak tekinteni. El kell számolni tehát azzal a ténnyel, hogy vannak olyan ismeretek, amelyeket a hagyomány résztvevói, sốt, voltaképpen a megtestesítôi és hordozói „kifelé” is relevánsnak tartanak, és vannak olyanok, amelyeket elsôsorban „befelé” tartanak annak. Nem azért, mert a befelé releváns ismeretek révén mindenekelő́tt elzárkózni kívánnak, meg akarják magukat különböztetni másoktól (hi-

${ }^{6}$ Vö. M. Oakeshott: „A politikai racionalizmus”. In A politikai racionalizmus. Szerk. Molnár Attila Károly. Budapest, 2001, Új Mandátum, 123-152. o. 
szen ezek az ismeretek is hozzáférhetók mindenki számára), hanem azért, mert a befelé releváns ismeretek alkalmazott ismeretek, amelyek csak az után válnak relevánssá, ha valaki már elfogadta a hagyományt hitelesítố tekintélyt. A különbségtétel e kétféle ismeret között a konzervatívok számára nagyon fontos, ugyanis az egyik a hagyományt megközelíthetôvé és elfogadhatóvá; a másik pedig élővé, gyarapodóvá teszi.

Ha ezeket a megállapításokat mármost az információs társadalomhoz tapadó fogalmak és képzetek körében is alkalmazni kívánjuk, akkor - konzervatív szemszögból - a következóképpen érvelhetünk: Az információtömeg semmilyen növekedése nem változtat azon a tényen, hogy vannak olyan ismeretek, amelyeket „kifelé” kommunikálunk, s így a csatlakozás, a bekapcsolódás lehetôségeit teremtjük meg; és vannak olyanok is, amelyeket „befelé” közvetítünk, ezáltal a fennmaradás, a továbblépés lehetốségét biztosítva. Sem ettól, sem az információtovábbítás technikai eszközeinek módosulásától nem várható, hogy ebben változás történik: sốt, az elmúlt évek egyik látványos fejleménye, hogy a személyesség, a személyes ismeretségból származó közös nyelv és közös érdeklődés, ami jórészt magukat a kapcsolatokat erôsíti, illetve az ezekból származó bonyodalmak és fejlemények a korábbi hivatalosabb, személytelenebb, tárgyszerû́ és hír típusú információk uralta kommunikációs terek egyre nagyobb részét foglalják el. A szappanoperák, valóságshow-k, sztárkeresố músorok, sportbajnokságok, internetes naplók, levelezốlisták, fórumok, csevegószobák mind intimitásteremtố eszközök. Egyes régóta ismert idegen nyelvú tévécsatornák (mint a német RTL vagy Sat1) gyakorlatilag élvezhetetlenekké váltak például a magyar nézố számára, mióta filmek helyett inkább show-músorokat, vetélkedóket, helyi sorozatokat közvetítenek. Ezeknek a követése olyan speciális tudás, ismeret meglétét tételezi föl a nézôtól, amit csak huzamos nézés és a valós térben szereplő személyekkel való utánkövetés révén (az eseményeket és a karaktereket kitárgyalva családi vagy baráti körben, a fodrásszal vagy a szomszéddal) - azaz részvétellel - lehet elsajátítani. Az SMS-küldésnek, az e-mail üzenetekben és a különféle fórumokon alkalmazott beszédmódoknak is rögzülnek bizonyos sajátosságai, szabályai, amelyek egy ismeretlen számára érthetetlenek vagy követhetetlenek is lehetnek. Olyan ez, mint amikor először lépünk egy idegen ország területére: a színek, a táblák, a gesztusok, az írásjelek olyan világa tárul elénk, amelyben van sok ismerôs elem is, de elég csak néhány ismeretlen vonás ahhoz, hogy teljesen félrevigyen, elbizonytalanítson minket. Az információs társadalomban nem annyira a közös tudás, mint inkább az óriási mennyiségú intim tudás a meglepó, ami ugyanolyan töredezetté teszi a társadalmat, mint amilyen a tömegkommunikációt megelőző korszakban volt vagy lehetett - csak itt nem családi és falusi vagy városi lakóhelyi közösségekról, hanem virtuális módon létrejövő, de nagyon is valóságos intim közösségekrôl van szó. A konzervatív mindezt voltaképpen elégedetten veheti tudomásul, noha nem az ô elveinek gyốzelméról van szó, hanem csupán azok igazolásáról. ${ }^{7}$

\footnotetext{
${ }^{7}$ Sok konzervatív hajlamos a kultúrpesszimizmusra, talán emiatt is látszik úgy, hogy a tömegkommunikáció és a magánkommunikáció technikai forradalmával alapvetốen szemben áll. Véleményem szerint azonban érdemes az ilyen felfogást vallóknak elgondolkodniuk a föntebb leírtakon is. Közismert tény például, hogy a nyolcvanas évek beszédközpontú kommunikációs korszakát, amely a távközlés fejlôdésével függött össze, az internet megjelenése miatt az írásbeliség - ráadásul a személyes írásbeliség(!) - reneszánsza követte.
} 


\section{Rend}

A második állítás úgy szólt, hogy a szokások és a rutinszerú cselekvések - köztük az információk, ismeretek továbbadására, rögzítésére, felhalmozására és kezelésére szolgáló eljárások - egyfajta renddé váltak; illetve hogy ez a rend a nyugati történelemben többször felborult, válságba került, majd forradalmi és ellenforradalmi, polgárháborús és megegyezéses úton újból megszilárdult. A renddé válás vagy szervezôdés folyamatának természetesen vannak tudatos és szándékolt, valamint nem tudatos vagy legalábbis nem szándékolt mozzanatai is. Ám függetlenül attól, hogy maga a folyamat milyen, a végeredmény - s ez az állítás lényege - mindenképpen az, hogy a társadalom tagjai rendként észlelik az életüket és tevékenységeiket meghatározó szokások és eljárások együttesét. Ez annyit jelent, hogy már nem elsôsorban tabuk és mítoszok, rítusok és egymással csak lazán összefüggố hiedelmek szervezik óket közösséggé, hanem olyan szabályok, amelyek - legalábbis elvben és várakozásaik szerint - koherens egészet alkotnak. Mindenhol, ahol a törvény, a jog uralma kifejezett formát ölt (a hellén poliszokban már egészen biztosan), a rend képzete is megjelenik. Elképzelhetô, hogy a rend esetlegesnek és megváltoztathatónak túnik; de az is, hogy egy kozmikus rendbe illeszkedônek, vagy legalábbis az elképzelhetố legtökéletesebbnek - mindez mostani szempontunkból másodlagos jelentôségú. A fontos az, hogy a rend, a rendezettség tudata révén az egyes ember képessé válik arra, hogy ismeretlen szituációkban, ismeretlen helyeken, ismeretlen emberekkel kapcsolatba lépve (vagy ilyen körülményeket csak föltételezve is) többé-kevésbé tájékozódni tudjon arról, hogy mi a teendô. A rend az, amit tulajdonképpen minden egyes polgár magával képes vinni. A mítosz, a tabu jobbára csak helyben múködik, s beavatottságot feltételez. A rend bárhol képes múködni, s így az egyént fölszabadítja a tér- és időbeli kötöttségek egy része alól. S a rend kialakulásának egyik mozঞanata, hogy bizonyos információk, ismeretek megfelelóképpen rögzülnek és múk ödni kezdenek. ${ }^{8}$

Lássunk egy konkrét példát, a tulajdonjog intézményét, amely kétségkívül minden társadalmi rend egyik alapintézménye. A tulajdonjog természetesen csak része a nagyobb egésznek. A tulajdonhoz füződő jogok korlátozottak: egyrészt más tulajdonjogok korlátozzák óket, másrészt a tulajdon használatára vonatkozó szabályok. Ezek illesztik bele a tulajdonjogokat a tágabb rendbe, de nem logikátlanul vagy önkényesen, hanem hasonlóképpen evidensnek elfogadott szabályok szerint. Mindazonáltal a tulajdonjogok önmagukban is jól mutatják a fent leírt jellegzetességeket. Elôször is, a rendezettség képzetét keltik: mindennek, amivel egy átlagembernek egyáltalán dolga

\footnotetext{
${ }^{8}$ Max Weber fejtegetései a rendról nem teljesen vágnak egybe az itt elmondottakkal. Weber elválasztja a rend legitimitásának a kérdését a rend fennállásának a kérdésétól (normativ és empirikus kérdés). A rend legitimitásának többféle alapja lehet, s zavaró, hogy ezck között szcrepel az is, hogy a rend fennáll. Továbbá Weber a rend fogalmát erőteljesen odaköti az uralom fogalmához. A tulajdonjog intézményének megértésében (lásd a következố bekezdést a főszövegben) az elóbbi észrevétel azért jelenthet problémát, mert nem biztos, hogy vissza kellene vagy lehetne vezetni valamelyik legitimitás-alapra, tehát meg lehetne benne különböztetni azt, amit a tulajdonosok - azaz mindenki - róla gondol, attól, ahogyan cselekszik. A másik észrevétel pedig azért okozhat félrećrtést, mert bár a tulajdon kérdései nyilvánvalóan hatalmi kérdések is, maga a tulajdonjog intézménye vagy viszonyrendszere anélkül is rend-szerú, hogy szükségképpen alá-fölérendeltséget implikáljon. (Vö. Gazdaság és társadalom. Budapest, 1987, KJK, 58-60.)
} 
akad ebben a világban, tulajdonosa van. S ez nemcsak a meglévő, hanem a még nem is létezố dolgokra is vonatkozik! Hiszen bármi, ami a meglévố dolgokból előáll, nyilvánvalóan valakié (egyéné, közösségé, intézményé) lesz. Ugyanez érvényes a múltra is: nincs elvi akadálya annak, hogy az ésszerúség határain belül tetszóleges idôpontig visszavezessük a dolgok tulajdonlását. A tulajdonjog nagyon fontos az ismeretlen környezetben való társadalmi tájékozódás és érintkezés szempontjából is: a tulajdon tiszteletben tartásával máris fontos alkalmazkodási múveletet hajtunk végre - s ugyanezt várjuk el másoktól is. Természetesen számos aktív társadalmi múveletet is lehetốvé tesz a tulajdonjog a termelés, a fogyasztás, a csere, az öröklés, a munka és a szabadidő terén egyaránt - az életnek mindezek az aspektusai elképzelhetetlenek volnának a tulajdonjog intézménye nélkül. A tulajdonjog személyében is felszabadítja az embert: a birtokomban lévố dolgokkal bárhol és bármikor rendelkezhetem, függetlenül attól, hogy fizikai közelségükben vagyok-e vagy sem; s tekintet nélkül arra is, hogy mi fog történni holnap vagy holnapután. ${ }^{9}$

Mármost világos, hogy a tulajdonjog intézménye számos probléma megoldását is megköveteli, köztük információs problémákét is. Elsôsorban a nyilvántartásét, azaz az információk (döntések, események) rögzítését. Másodsorban szükségessé teszi a konfliktusok megoldásának egységes eljárásrendjét. Harmadsorban elôírja az eljárásokra vonatkozó ismeretek alkalmazásának szabályait, negyedsorban pedig megteremti az ilyen ismeretek egységes átadására szolgáló intézményeket (egyetemeket, bíróságokat, törvényszékeket stb.). Az sem lehet kétséges, hogy az ily módon kialakult és üzemszerúvé váló rend az egyes egyén szempontjából nem egyszerúen „külsô”, hanem legalább annyira „belsố” is, azaz egyetértést, jóváhagyást követel meg tôle, sốt még azt is, hogy a személyes kapcsolatokban is fontosnak tartsa és megkövetelje ennek a rendnek a követését (a gyermeknevelés során az enyém-tied személytelen, össztársadalmi szintû́ rendjének elsajátíttatása a szülók egyik legösszetettebb feladata). Ezeknek az intézményeknek és viselkedéseknek a létrejöttéhez egymást erôsítố és támogató folyamatok vezetnek, $s$ magának a tulajdonjognak az intézményesülése is részben azonos ezeknek a problémáknak a megoldásával.

A tulajdonjog intézménye csak része a társadalmi-politikai rendnek. Más példákat is föl lehetne hozni: többek között a jogalkotás, a végrehajtás, az igazságszolgáltatás, a szerzốdéskötés eljárásait, szabályait és szokásait. Ezek mindegyikéhez seregnyi hasonló kérdés kapcsolódik az ismeretek rögzítésével, értelmezésével és továbbadásával összefüggésben. Az információs és kommunikációs technológiák változása önmagában itt sem mutat új irányba. Azzal, hogy az interneten vagy telefonon adunk-veszünk, intézzük pénzügyeinket, vagy így veszünk részt döntések meghozatalában, nem forgatjuk föl például a tulajdonviszonyok fenntartotta rendet vagy a politikai kompetenciákat, hanem csak erőforrásainkat reallokáljuk, és tovább növeljük fizikai-idóbeli szabadságunkat. A távíró megjelenése elốtt a tốzsdék az újságok esetleges megbízhatóságú híreire reagáltak, ma pedig már egymás napi záróértékeire figyelnek, de mindkét esetben az információszerzés gyorsasága az, ami számít. Az idóbeli kockázatterítés új pénzügyi technikáival nem a bizonytalanság, hanem a bizonyosság, a kiszámíthatóság és a tervezhetôség, vagyis az idő fölötti uralom eszközei bóvültek, azaz nem annyira a

\footnotetext{
${ }^{9}$ Vö. Svetozar Pejovich: A tulajdonjogok közgazdaságtana. Budapest, 1992, KJK.
} 
váratlan fejlemények, mint inkább a stabil és egyenletes növekedés korszaka köszöntött be. Ezek persze nagyon általános kijelentések, hiszen a hibázás, a tévedés lehetốségei ettól semmivel sem lettek kisebbek. Viszont az alapképlet változatlan maradt, vagy akár még meg is szilárdult: a rend, a rendezettség messze fontosabb minden váratlan információs aszimmetriából származó haszonnál, egyszerúen azért, mert a haszon realizálása a rend nélkül nem lehetséges. A konzervatív számára ebból az a következtetés adódik, hogy a rend alapjainak megốrzése és stabilizálása - ha azokat veszély fenyegeti fontosabb, mint az információs technológiák terjedése vagy nem terjedése önmagában. A konzervatív nem elsốsorban vásárolni és ügyintézni akar az interneten, bár ennek az elônyeit sem veti meg, hiszen ố is szereti a kényelmet, hanem inkább arra ügyel, hogy a rendet felforgatni igyekvố eszmék elő́tt gátat emeljen. Egyúttal helyesli mindazokat az intézkedéseket és javaslatokat, amelyek a felelôsség és a számonkérhetôség szempontjait kívánják érvényesíteni az információkkal való kereskedés és gazdálkodás, illetve azok alkalmazása terén is, legyen az a szúken vett gazdasági viszonyok területe vagy a politikai-közigazgatási szféra.

\section{Funkció}

A nyugati társadalomfejlôdés harmadikként említett jellegzetessége a funkcionális szemlélet. Ennek legósibb - ugyanakkor legkevésbé elavult - változata a természetes munkamegosztás egyéni és közösségi elônyeiból indul ki. A társadalom ebben a felfogásban egyének és társulások speciális képességeinek, erőforrásainak, tudásának, ismereteinek és tapasztalatainak a kiaknázása és kölcsönös elốnyszerzésre való felhasználása. Elófordulhat, hogy ezeket a speciális tudás- és ismeretformákat, képességeket egyenesen társadalomszervezố erốvé is emelik, azaz politikai jelentôséggel is felruházzák. A társadalom politikai metszete - legalábbis e felfogás szerint - nem a vezetô és a vezetett osztályból, hanem a természetes munkamegosstás révén létrejövő funkcionális osztályokból áll: a legáltalánosabb felosztás szerint földmúves (vidéki), kézmúves/iparos (városi), kereskedő (vidék és város közötti), valamint írástudó, védelmezó és szakrális tevékenységeket ellátó osztályok vannak (ennek a felosztásnak a nyomai még a legmodernebb kormányzatok miniszteriális struktúrájában is jól kivehetôk). Ezt a felfogást vallotta a rendies középkor domináns politikai filozófiája is, amelyet a hivatásrendikorporatív állam 20. századi koncepciói igyekeztek korszerúsíteni. ${ }^{10}$

Az Adam Smith-féle láthatatlan kéz koncepciójának szintén fontos skolasztikus gyökerei vannak, és ez sem arra utal, hogy egy láthatatlan kéz gondviselésszerúen rendet teremt a társadalmi káoszban, hanem arra, hogy a munkamegosztás egyszerú, mindennapos elónyei is elegendốek a rend magyarázatához. A Smith-féle munkamegosztás azonban az eredeti gondolat radikalizálása is, hiszen a kölcsönös elốnyök eszméje itt nem az osztályok, hanem az egyének szintjére van lebontva.

${ }^{10}$ Itt nemcsak a fasiszta államok kísérleteire kell gondolni, hanem demokratikus államok korporatív struktúráira, a különböző érdekegyeztetô tanácsok, szakmai kamarák állami felelôsséggel való felruházásának példáira is. 
A funkcionalista társadalomelmélet klasszikusai ezzel szemben ismét a közösség szintjén ragadják meg a különbözố társadalmi funkciókat és feladatokat, noha nem osztályokat, hanem rendszereket rendelnek egymás mellé. ${ }^{11}$

Mindegyik felfogásban másként merülnek föl az információkkal kapcsolatos problémák, de egyikben sem mellékesek. A szakmák és szakmai társulások alapvetô információs problémája a kompetenciák megítélésének, számontartásának és számonkérésének a megbízható rendszere. Ahhoz, hogy a társadalmi specializáció - akár egyének, akár csoportok, akár osztályok szintjén - megfelelố hatékonysággal múködjön és fennmaradjon, ki kell épülniük olyan intézményeknek, szabványoknak és mércéknek, amelyek a munkavégzés, a teljesítmény, a hasznosság mérését és elszámolását megfelelően rögzíteni tudják. Az iskolai bizonyítványok, önéletrajzok, nyilvános tantervek, tudományos fokozatok, ajánlólevelek, munkakönyvek - hogy csak néhány konkrétumot ragadjak ki - a kompetenciáról való tájékozódás megkerülhetetlen eszközei. Ezek az eszközök nyilvánvalóan nem a modern társadalom szülöttei.

A modern közgazdaságtudomány, amely a munkamegosztást az egyénekre lebontva értelmezi, az árakra koncentrál, s azokban elsôsorban információt lát. Az árak jelentik a legfontosabb információkat ahhoz, hogy mit érdemes termelni, milyen szolgáltatást érdemes nyújtani, hogyan érdemes az erôforrásokat allokálni, hogyan célszerú a fogyasztói preferenciákat rangsorolni - magyarán: hogyan lehet a társadalmi munkamegosztásba a legmegfelelóbb módon bekapcsolódni, illetve abban részt venni. Mióta piaci ár létezik (s ez jóval a kapitalizmus elốtti idókre is igaz), azóta a gazdasági tevékenység a javak fizikai elôállítása mellett igen nagy mértékben információszerzésból és az információk értékeléséból áll.

A funkcionalista iskola legkifinomultabb, luhmanni elméletében kifejezetten központi kérdés, hogy a differenciálódott alrendszerek hogyan kapcsolódnak egymáshoz. Az elmélet szerint a kapcsolatok úgynevezett generalizált, szimbolikus, kommunikatív kódok révén valósulnak meg. ${ }^{12}$ Ezek a kódok voltaképpen mércék, két értéklehetôséggel (hasznos-haszontalan; fizetóképes-fizetésképtelen; igaz-hamis; szeret-nem szeret stb.). Mindegyik kód képes a társadalmi cselekvések jelentős részének értékelésére, a maga módján. A társadalmi alrendszerek ezek révén integrálódnak, noha közben értelemszerúen állandóan ütköznek is. Az egyének számára ezek a kódok tólük függetlenül múködó, mégis általuk múködtetett értékelések, azaz a másik félnek szóló közlések arról, hogy milyen cselekvést várnak el vagy milyen cselekvésre készülnek. A funkcionalista társadalomelmélet luhmanni változata ebból a szempontból nyugodtan nevezhetô információs társadalomelméletnek is, de szem elốtt kell tartani, hogy az elmélet nem kötődik kizárólagosan a modern társadalmakhoz, illetve azok kialakulását nem törésnek, hanem folytonos fejlődés és differenciálódás eredményének tartja.

\footnotetext{
${ }^{11}$ Mindmáig a legjobb, tömör áttekintés magyar nyelven: Csepeli György - Papp Zsolt - Pokol Béla: Modern polgári társadalomelméletek (Budapest, 1987, Gondolat).

${ }_{12}$ Talcott Parsonsnál is alapvető tétel, hogy az alrendszerek médiumok révén kapcsolódnak egymáshoz (ilyen a hatalom, a pénz, a befolyás, az értékkötelékek - legalábbis a nagy alrendszerek szintjén), de nála nincs hangsúlyozva ezek kommunikatív, azaz információs tartalma. Luhmann kommunikációfelfogásáról lásd Balogh István - Karácsony András: Német társadalomelméletek. Budapest, 2000, Balassi, 309-314.
} 
A funkcionalista társadalomelmélet túllép a munkamegosztásra épülő felfogásoknál, s ez a modern nyugati társadalmak intézményrendszerének ismeretében teljesen magától értetődő. Az egyetemi-iskolai szféra, a közigazgatás, a kulturális intézményhálózat, az egyházak és a sajtó kialakulása azonban nem váratlan és új fejlemény, hiszen mindegyik szektornak komoly történelmi múltja van. Minthogy azonban társadalmi feladatuk és felelốsségük nem annyira valamilyen speciális ismeretanyag felhalmozása, átadása, illetve a kompetenciák számontartása, hanem mindegyikükre átfogó, holisztikus felelősség hárul az egyének és a társadalom életében egyaránt, legfontosabb információs problémájuk - a funkcionális megközelítést szem elő́tt tartva - a teljes körú felelősségnek való megfeleléshez szükséges információk, ismeretek összegyújtése, tárolása és kezelése, sốt, nem kis mértékben azok előállítása is. A polgárok azt várják el, hogy az egyetemek a tudomány minden ismeretét legyenek képesek továbbadni; a közigazgatás legyen tisztában az ország erőforrásaival, lehetôségeivel és problémáival; a kulturális intézmények az emberiség minden kulturális kincsét közvetíteni tudják; az egyházak számára „semmi se legyen idegen, ami emberi”; a sajtó pedig kimerítően tájékoztasson minden fontos hírról, és adjon teret minden fontos véleménynek. Ezek az elvárások természetesen nem függetlenek attól, hogy ezeket a felelősségeket és funkciókat a kérdéses intézmények el is vállalják, s ezzel saját maguk is hozzájárulnak az elvárások keltéséhez.

Vegyük közelebbról szemügyre példaként a közigazgatás rendszerét. A modern államszervezet kialakulásának története (az államszervezetet itt azonosnak tekintem a közigazgatással) koherens módon leírható az információgyújtés és -feldolgozás technikáinak történeteként. ${ }^{13}$ A legkülönfélébb adatok gyưjjtése az ország természeti erôforrásairól és jellemzôiról, lakosságáról és a lakosok különféle viszonyairól, majd ezek tudományos-statisztikai módszerekkel való feldolgozása, azután pedig politikai programok hozzájuk szabása a 17. századtól kezdve bontakozott ki egyre határozottabban. Ahhoz, hogy egy bizonyos problémát megoldjunk, mindenekelőtt reális, de számokkal kifejezhetô képet kell kapnunk a lehetôségekról és a képességekról, ez pedig információ- és adatgyưjtés (és részben előállítás) kérdése. A meghozott döntések végrehajtásáról ugyancsak állandó adatszolgáltatásra van szükség, egyébként nem volna értelme belefogni. A különféle döntések és programok és azok értékelései önmagukban is az adatgyưjtés és adattárolás tárgyai, s a további döntések és programok információs inputjai. A funkciók kérdése tehát egészen radikálisan veti föl az információk gyứjtésének, előállításának, tárolásának és fölhasználásának a problémáit.

Ügyelni kell azonban arra is, nehogy a funkcionális szemlélethez rendelhetố információs problémákat kizárólag a társadalom, az állam, illetve az említett intézmények, intézményrendszerek vagy hálózatok szintjén lokalizáljuk. Ahhoz, hogy ezek az intézmények jól múködjenek, arra is szükség van, hogy az egyének a maguk magánháztartásaiban, családi és társas vagy teljesen individuális köreiben is alkalmazzák a funkcionális szemléletet. A modern kapitalista gazdaságban szükséges újszerú számviteli szemlélet mindenekelótt a magánszférában terjedt el. A modern állam nem az ókori hivatalnok-óriásállam új kiadása. Az egyének és az óket irányító, róluk adatokat gyưjitô állami intézmények gondolkodásmódjának összhangja, hasonló irányultsága nélkül alig-

\footnotetext{
${ }^{13}$ Vö. Szakolczai Árpád: A fejlôdés megkérdójelezése. Budapest, 1990, Akadémiai.
} 
ha volna képes sem az állam, sem az egyén a tóle elvárt racionális és funkcionális cselekvésekre.

Hogy ezt a nagyon fontos analógiát jobban értsük, gondoljunk például egy modern napilap vagy internetes hírportál szerkezetére. Ezek az egyének számára fontosnak, általuk elvártnak vélt funkcionális rend szerint szerveződnek (természetesen technikailag másként, hiszen az interneten másként lapozgatunk, mint a napilapokban). A funkcionális rendezốdés értelemszerúen nem munkafajták, szakmák szerint történik, hiszen ezek sokféleségét gyakorlatilag lehetetlen áttekinthetố módon reprezentálni, arra valók a szakmai hírlevelek, folyóiratok. Ezek az orgánumok egy általánosabb logikát követnek, nevezetesen a modern társadalomban való megfelelő „funkcionálás” logikáját: az olvasót „nyilván” érdekli a kül- és a belpolitika, a gazdaság, az idôjárás, a sport, a szórakozás, a tudomány, a kultúra, esetleg a vallás. Ezen a klasszikus beosztáson az internet megjelenése jottányit sem változtatott. A klasszikus struktúra kialakulásának pontos menete és háttere most másodlagos kérdés, a lényeg az, hogy a hírek és információk elrendezése az egyéneknek a tágabb és szúkebb társadalmi környezetükbe való zökkenőmentes funkcionális beilleszkedését szolgálja.

Hogyan vélekedhet minderról a konzervatív világképpel megáldott polgár? Egyfelól itt is fölismeri, hogy az alaptendenciák lényegüket illetốen változatlanok, következésképpen nem érez semmilyen radikális cselekvést (változtatást, védelmet) sürgetônek. Másfelól nem lát okot arra, hogy a kommunikációs és információs technológiák fejlốdésétốl régi vágyát, az állami gondoskodás és a közvélemény befolyásának lazulását beteljesedni lássa. Továbbra is úgy véli, hogy a viszonylag autonóm ítéletalkotás kevesek kiváltsága marad, amin a mondott technológiai változások nem sokat változtatnak. Ezt azonban nem feltétlenül tekinti tragédiának, pontosabban igyekszik ellenállni a kísértésnek, hogy az érintettek beleegyezése és jóváhagyása nélkül - mondjuk állami segédlettel - gyökerestül új alapokra igyekezzen helyezni a modern társadalmat. Az egyének elég jól ki tudják használni az új technológiák és technikák adta lehetôségeket, s ennek az a legfontosabb feltétele, hogy rá legyenek kényszerítve, vagyis a társadalomba, a gazdasági tevékenységbe való bekapcsolódásuk a saját érdekük legyen. Magyarán: nem azzal segítünk rajtuk, ha kérés és kérdezés nélkül ellátjuk óket olcsó eszközökkel, hanem azzal, ha a különféle ingyenes szolgáltatásokat és juttatásokat megvonjuk tólük, illetve csak azzal a föltételekkel biztosítjuk ezeket részükre, ha megélhetésükról igyekeznek saját maguk gondoskodni. A mobiltelefon-hálózatok elképesztő sebességú kiépülése jó példa erre: ez állami segédlet nélkül zajlott, a tág értelemben vett gazdasági racionalitás bốségesen elengedốnek bizonyult ahhoz, hogy a távközlés területén ez a változás Magyarországon (is) végbemenjen.

\section{Tudomány}

A nyugati társadalmakban kialakult egy olyan tudásforma, amely a természetról, késóbb a társadalomról, az emberról is világos módszertani elveknek megfelelően gyújtött és értékelt adatok, információk együttese. Ezzel a tudásformával sajátos tevékenységformák és hivatások járnak együtt, amelyek a jövớre irányulnak, a haladás és a fejlôdés képzetével szoros összefüggésben. Ez a rendszerezett tudásforma a tudomány. 
Itt sem modern fejleményrôl van szó. A bevezetóben Arisztotelész nevét ragadtam ki a tudománytörténet kezdetének nagy nevei közül, elsősorban azért, mert az adatgyújtés és az adatfeldolgozás, az értelmezés és a gyakorlati orientáció kivételes egyensúlyban van nála. A szakadatlan fejlődés és haladás gondolata nála még hiányzik, elsôsorban azért, mert egészen más filozófiai világképpel rendelkezik. Ezt megtévesztố volna „statikusnak” nevezni, hiszen a „haladás”, a „mozgás” eszméje is kulcsfontosságú benne, csak éppen nem indeterminált, célszerútlen vagy önmagából meghatározhatatlan. A modern tudomány - elsôsorban a természettudomány - kiindulópontja azonban nem felel meg az arisztotelészi világképnek: a természet folyamatainak, törvényeinek megértéséhez nem szükséges a dolgok teleologikus-dinamikus látásmódja. A dolgok statisztikai-matematikai összefüggésben állnak ugyan egymással, de ez mechanikus, végsố soron értelem nélküli összefüggésrendszer, s tulajdonképpen sokkal statikusabb képet sugall, mint az arisztotelészi tudományfelfogás. Ugyanakkor a célszerúség, vagy inkább a belsố értelem gondolata nagyon is egybevág a modern tudomány önmagáról alkotott képével: a tudós munkájának végsố soron az ad értelmet, hogy hozzájárul az emberiség haladásához, boldogulásához. A modern tudományra születése óta ez a kettôsség jellemzố: a természet világára nézve egyre kevésbé érzi kényszerítônek az arisztotelészi világkép elfogadását, ugyanakkor az emberiség sajátos céljainak elérésében egyre fontosabbnak véli saját szerepét. A tudománytörténet szociológiai, történészi megközelítései bőségesen illusztrálták ezt az utóbbi állítást.

Részben talán az arisztotelészi felfogás elvetése vagy háttérbe szorulása is az oka annak, hogy a modern tudomány egyik legalapvetóbb vonása az információ- és adatgyưjtés eszközeinek hihetetlen kifinomodása és a gyứjtött adatok tömegének exponenciális növekedése. Semmilyen elôzzetes elképzelés nem tartható önmagában helytállónak, illetve minden elképzelés, hipotézis csakis az ellentétes adatok, megfigyelések fölbukkanásáig fogadható el. A befolyásos popperi falszifikációs elmélet értelmében minden egyes adat, információ potenciálisan alkalmas arra, hogy egész világmagyarázatokat rendítsen meg. A cáfolat lehetôsége hajtja, úzi elốre nemcsak a tudóst, hanem az interneten keresgélő átlagembert is, akit rendszerint jobban érdekel az, ha valamilyen általánosan „elfogadott” nézet megcáfolásának ígéretével találkozik, mint maga a szóbanforgó nézet. Talán nem megyek túl messzire, ha ebben az információvadászatban tabudöntögetố, demokratikus alapélményeket megjeleníteni és megerôsíteni képes attitúdöt látok, amelyhez a tudományos világkép adja az ösztönös igazolást (értsd: bárki rálelhet éppen arra az információra, amely kifordítja a sarkaiból a világot).

A haladás képzete viszont, ahogy említettem, nagyon is jól illeszkedik az arisztotelészi teleologikus világképhez. A modern tudós hitvallása általában szintén úgy szól, hogy tevékenysége közvetve vagy közvetlenül hozzájárul az emberiség jólétéhez. Ennek a jellegzetességnek az információs aspektusa áttételesebb, mint az elôzóé. Ez az egyénekben a naprakészség, a jövőre orientáltság, a „,jelenlevés” sürgető ösztöneként jelentkezik, amely a technológiai-technikai változások nyomon követésének és azonnali alkalmazásának a kényszerét válthatja ki, tekintet nélkül azok szükségességére és valódi jólétnöveló hatására (jó példa erre az az ötlet, hogy már az óvodákat is lássuk el számítógépekkel).

Természetesen mind a két jellegzetességet - az információk, adatok függetlenségének hipotézisét és a haladáshitet - éles és közismert bírálatok is érték. A legtöbb tu- 
dományág tapasztalati alapon áll (a matematikát és a logikát szokták csak spekulatívnak nevezni). Ez annyit tesz, hogy a tudomány igyekszik a lehetó legjobban megszabadulni az elméleti előföltevésektól, amikor hozzálát, hogy tárgyáról információkat gyújtsön, illetve azokat fölbontsa, összekapcsolja és rendezze. Komoly tudósnak persze ma már nincs illúziója a teljes előföltevés-mentesség lehetségességéról. Minden tapasztalat, információ eleve jelent valamit, ha másért nem, akkor azért, mert más információkhoz és tapasztalatokhoz kapcsolódva azon nyomban a megerósítés vagy az ellentmondás jelentését veszi föl (de általában ennél sokkal többet jelent). Thomas Kuhnnal szólva: minden adat, ismeret csak egy paradigmában az, ami. Ezért minden tudományos ismeret csak a tágabb összefüggés ismeretében érthetố meg. Ezeknek az összefüggéseknek az ismerete pedig nem egyszerúen adatok és információk ismerete, hanem logikai mûveleteké és asszociációké is.

Itt kétféleképpen lehet alaposan mellényúlni. Az egyik veszélyforrás az, ha az ember, aki természetesen mindig az adatok és megfigyelések „tudományos” rendezésére és a köztük lévő összefüggések rekonstruálására törekszik, egyszerúen nem veszi a fáradságot ahhoz, hogy részletesen tájékozódjon. Ennek nem a megértés elmaradása, hanem a dolgok leegyszerúsítése lesz a következménye: gondoljunk a „globalizációról”, a „kapitalizmusról”, a „politikáról” és más nagy kérdésekról kialakított és hangoztatott sekély színvonalú vélemények tömegére, amelyek azonban mindig a „tudományos”, vagy legalábbis az „elfogulatlan” jelzôvel büszkélkednek. A másik mellényúlás akkor történik meg, amikor a legegyszerúsített sémák és világnézetek követôi nagyon is sok idốt szánnak kedvenc teóriáik alátámasztására és lelkes adatgyújtoóvé válnak, csak éppen - a tudományos eljárás karikatúrájaként - kizárólag a saját végletesen leegyszerúsített „paradigmájukat” finomítják a végtelenségig, hihetetlen szívóssággal gyújtve az azt alátámasztó információkat és adatokat. Bármilyen közhelyesen is hangzik, a konzervatív felfogású ember egyrészt nyugtázza, hogy amit a maga részéról mindig is gondolt a tudomány eszméktốl és világnézetektól való függetlenségének lehetetlenségéról, azt ma már széles tudósi körben osztják; másrészt viszont óvakodik attól, hogy az adatok és információk esetlegességéból és elméletfüggóségéból a „mindent be lehet bizonyítani” tételt vezesse le. Az alapos, de nem egysíkú tájékozódás, a szükséges és helyes előfeltevések kritikai vizsgálata, s a következtetések korlátozott érvényének tudomásulvétele talán nagyon általános és közhelyes, mégis csak komoly erốfeszítések révén megtartható előírás.

A haladással szembeni végletes szkepszis sem lehet a konzervatív világkép része. A haladás gondolatának teljes elvetése az arisztotelészi világkép elvetése is volna, ami ezer egyéb okból sem tanácsos a konzervatív gondolkodású ember számára. A konzervatív filozófusok egyik kedvenc témája ugyan a haladáshit bírálata, a múltra való reflexió fontosságának sokoldalú alátámasztása; s mindehhez a történelem, kiváltképpen a 20. században, bôséges és szomorú bizonyítékokkal szolgál. De a nyugati gondolkodásban a cél felé való haladás és törekvés, a dolgok végső elrendezésének eszméje túlságosan is erôs és meghatározó ahhoz, hogy a konzervatív kétszer is meggondolja, hogy valóban ki akarja-e irtani a lelkekból. A tudomány haladásának és a technikai fejlôdésnek tagadhatatlan jóléti hatásai voltak és vannak, amelyek mély ösztönöket és igényeket elégítettek ki (az élet meghosszabbítása, mozgásszabadság, sokszínúség, az emberi kapcsolati lehetőségek növekedése). Mindez a legkevésbé sem lehet a konzervatív fel- 
fogású ember ellenére, akinek természetesen még ennek belátásával sem szabad elveszítenie érzékenységét a haladáshitból fakadó értelmetlenségek (mint például az említett óvodai számítógépek) iránt.

Minthogy a tudomány alapvetô fölismeréseit az iskolában sajátítjuk el, miközben a kommunikációs eszközök forradalma az iskolán kívüli életet befolyásolja a leggyorsabban, a két világ finom és józan összehangolása látszik a legsürgetóbb feladatnak. Személyes véleményem szerint az iskolai tananyagokban az egyes szaktárgyak keretein belül mindenképpen érdemes volna alaposan oktatni a tájékozódás módszereit: Mit keressek? Hol keressem? Milyen mélységig menjek el? Ez elvileg mindig is így volt: a könyvtárhasználat és egyes speciális tévémúsorok korábban is szerves részét jelentették - ha nem is mindenhol - a tanári munkának. De nagy hiba volna az ismeretszerzés és -bővítés funkcióját háttérbe szorítani. Alapos ismeretek nélkül nem lehet alapos elemzésre számítani, csak durva leegyszerúsítésekre és veszélyes általánosításokra. Talán nem teljesen életidegen gondolat, hogy ezt az összehangolást segítené a szülók bevonása az iskolai nevelési tevékenységbe.

Ám itt túlléptem az elemzés határain. Következzék az összefoglalás: állításom szerint a modern információs társadalom nem hozott magával teljesen új problémákat, mivel az ebben a fogalomkörben felvetett jellegzetes kérdések gyakorlatilag egyidôsek a nyugati civilizációval. Ennélfogva a konzervatív gondolkodás számára is jól ismert, klasszikus kérdésekról van szó. Ezek közül a konzervatívok számára általában kiemelten fontos négy kérdéskört, a hagyomány, a rend, a funkció és a tudás (a tudomány) jelenségcsoportjait vettem szemügyre. Mindenhol az említett kérdéseket tartottam szem elốtt, mindegyiknél kitérve napjaink változásainak értelmezésére is. A konzervatív gondolkodás semmiképpen sem ellenséges vagy gyanakvó az információs technológiák és technikák, eszközök fejlődésével, terjedésével szemben. Ső́t, fejtegetéseim inkább azt támasztják alá, hogy mivel lényeges társadalmi változások nem rajzolódnak ki a horizonton, maradnak a klasszikus kérdések és érvényesek a klasszikus válaszok is. 